\title{
Effects of Continuous Plastic Film Mulching on Soil Bacterial Diversity, Organic Matter and Rice Water Use Efficiency
}

\author{
Meiyan $\mathrm{Wu}^{1}{ }^{*}$, Ruochao Hao', Lianghuan $\mathrm{Wu}^{2}$ \\ ${ }^{1}$ Engineering Research Center of Wetland Agriculture in the Middle Reaches of the Yangtze River, Ministry of \\ Education, Hubei Provincial Key Discipline of Crop Science, Yangtze University, Jingzhou, China \\ ${ }^{2}$ Zhejiang Provincial Key Laboratory of Subtropical Soil and Plant Nutrition, College of Environmental and \\ Resource Sciences, Zhejiang University, Hangzhou, China \\ Email:wumeiyan2002@163.com, haoruochao@163.com,finm@zju.edu.cn
}

Received 6 May 2015; accepted 6 April 2016; published 11 April 2016

\begin{abstract}
Two field experiments were conducted to study the effects of 6-year plastic film mulching on bacterial diversity, organic matter of paddy soil and water use efficiency on different soils with great environmental variabilities in Zhejiang Province, China, under non-flooding condition. The experiment started in 2001 at two sites with one rice crop annually. Three treatments included plastic film mulching with no flooding (PM), no plastic film mulching and no flooding (UM), and traditional flooding management (TF). Soil samples were collected and analyzed for bacterial diversity by DGGE and organic matter content, and water use efficiency (WUE) was calculated. The results showed that PM treatment favored the development of a more total bacterial community compared with TF management, the total number of bands was 33.3, 31.7 at tiller stage and heading stage $\left(\mathrm{p}<0.05^{*}\right)$. Hence, organic matter content was decreased by $36.7 \%$ and $51.4 \%$ under PM at two sites. PM also produced similar rice grain yield as TF at Duntou site and Dingqiao site, the average was $7924 \mathrm{~kg} \cdot \mathrm{ha}^{-1}$ and $7015 \mathrm{~kg} \cdot \mathrm{ha}^{-1}$ for PM and $8150 \mathrm{~kg} \cdot \mathrm{ha}^{-1}$ and $6990 \mathrm{~kg} \cdot \mathrm{ha}^{-1}$ for TF, respectively. Compared to TF, WUE and irrigation water use efficiency were increased significantly by $\mathbf{7 0 . 2 \%}-\mathbf{8 0 . 4 \%}$ and $\mathbf{2 7 3 . 7 \% - 1 3 0 0 . 0 \%}$ for PM. It is essential to develop the water-saving agriculture.
\end{abstract}

\section{Keywords}

Rice (Oryza sativa L.), Water Use Efficiency, Water-Saving Agriculture, Bacterial Diversity

\section{Introduction}

Rice (Oryza sativa L.) is one of the major staple food crops in China. About $86 \%$ of the total water in China has

${ }^{*}$ Corresponding author.

How to cite this paper: Wu, M.Y., Hao, R.C. and Wu, L.H. (2016) Effects of Continuous Plastic Film Mulching on Soil Bacterial Diversity, Organic Matter and Rice Water Use Efficiency. Journal of Geoscience and Environment Protection, 4, 1-6. http://dx.doi.org/10.4236/gep.2016.44001 
been consumed in agriculture, of which $90 \%$ is consumed by rice production [1]. Owing to the pressure from large populations and water shortage for agriculture, it is urgent to develop water-saving and higher-yielding techniques for rice production. Plastic film mulching with no flooding (PM) has been adopted and developed as a new rice cultivation technique in China since the 1980s, and the total planting area under this management regime has reached 100,000 ha [2]. It is substantially different from both traditional flooded rice cultivation and rain-fed rice cultivation. PM regime plastic film is used during rice-planting stages under non-flooded conditions, and only $30-50 \mathrm{~mm}$ per irrigation is applied when soil water content falls below $80 \%$ of soil field capacities from transplanting to tiller stage. The use of this new cultivation regime has led to soil temperature and the growth of weeds has also been inhibited [3].

Soil microorganisms contribute to soil quality and regulate many ecosystem processes such as nutrient transformations and litter decomposition, as well as influence soil structural and bioremediation [4]. Both changes in soil microbial communities resulting from ecosystem management and global change can have significant impacts on ecosystem dynamics [5], and microorganisms respond sensitively to changes and environmental stress because they have intimate relations with their surroundings [6]. Therefore, interest in quantifying impacts on the biotic and abiotic component has increased with concern for the sustainability of agricultural ecosystem.

However, there is little information regarding the changes of organic matter content, bacterial community structure and water use efficiency under plastic film mulching with non-flooding conditions. In a 2-year study, Liu and Wu [7] showed the influence of PM on certain soil properties. In a rice-wheat cropping system, Liu et al. [8] reported the changes of nutrient uptake and nutrient balance in soil under plastic film mulching with nonflooding conditions. Hence, the objective of the present study is to investigate the effects of continuous plastic film mulching on organic matter content, bacterial community structure and water use efficiency. It is important for developing the water-saving agriculture.

\section{Materials and Methods}

\subsection{Site Description}

The field experiment was initiated in May 2001 at Duntou Town of Lanxi $\left(29^{\circ} 19^{\prime} \mathrm{N}, 119^{\circ} 43^{\prime} \mathrm{E}\right.$ and $72.8 \mathrm{~m}$ elevation above sea level) and Dingqiao township of Haining city $\left(30^{\circ} 26^{\prime} \mathrm{N}, 120^{\circ} 39^{\prime} \mathrm{E}, 12.8 \mathrm{~m}\right.$ elevation above sea level), which located in the Hangjiahu Plain and Jinqu Basin, Zhejiang Province, China. Average annual temperature is $17.7^{\circ} \mathrm{C}$ and $15.7^{\circ} \mathrm{C}$, annual precipitation is $1399.8 \mathrm{~mm}$ and $1220.3 \mathrm{~mm}$, cumulative temperature above $10^{\circ} \mathrm{C}$ is $5532^{\circ} \mathrm{C}$ and $4170^{\circ} \mathrm{C}$, annual frost-free days are $265 \mathrm{~d}$ and $231 \mathrm{~d}$, total sunshine hours is $1981.6 \mathrm{~h}$ and $2021 \mathrm{~h}$, respectively. The soil is referred to as Fec stagnic Anthrosols. Its properties are shown in Table 1.

\subsection{Field Experiment Design and Management}

The experiment was a randomized complete block design with three treatments and three replications. The three treatments were plastic film mulching with no flooding (PM), no plastic film mulching and no flooding (UM), and the traditional flooding management (TF). The plot size was $15 \mathrm{~m}^{2}$. The TF plots were isolated from the PM and UM plots by a $2 \mathrm{~m}$ wide alley with plastic film vertically buried to a depth of $60 \mathrm{~cm}$. The other plots were separated by $0.5 \mathrm{~m}$ wide irrigation furrows with two $0.3 \mathrm{~m}$ wide levees at two sides of the furrows. For the TF

Table 1. Soil physical and chemical characteristics.

\begin{tabular}{ccc}
\hline Parameters & Duntou & Dingqiao \\
$\mathrm{pH}$ & $5.10 \pm 0.15$ & $23.11 \pm 1.42$ \\
$\mathrm{OM}\left(\mathrm{g} \cdot \mathrm{kg}^{-1}\right)$ & $23.79 \pm 1.42$ & $1.90 \pm 0.35$ \\
Total N $\left(\mathrm{g} \cdot \mathrm{kg}^{-1}\right)$ & $2.28 \pm 0.20$ & $1.08 \pm 0.08$ \\
Total P $\left(\mathrm{g} \cdot \mathrm{kg}^{-1}\right)$ & $1.58 \pm 0.03$ & $165.28 \pm 5.06$ \\
Available $\mathrm{N}\left(\mathrm{mg} \cdot \mathrm{kg}^{-1}\right)$ & $142.53 \pm 5.14$ & $11.54 \pm 0.61$ \\
Available P $\left(\mathrm{mg} \cdot \mathrm{kg}^{-1}\right)$ & $88.46 \pm 3.00$ & $103.74 \pm 2.37$ \\
Available $\mathrm{K}\left(\mathrm{mg} \cdot \mathrm{kg}^{-1}\right)$ & $212.94 \pm 3.29$ & \\
\hline
\end{tabular}


treatment, the plots were flood-irrigated every 3 - 5 days to maintain a $3 \mathrm{~cm}$ water depth until 2 weeks before rice harvest. For the PM and UM treatments, no permanent water depth on soil surface was maintained during the rice growing season. From transplanting (early May) to tilling stage (early June), limited irrigation (30 - 50 mm per irrigation) was applied on PM and UM when soil water content fell below $80 \%$ of soil field capacities. The irrigation amounts and rainfall for the treatments were measured and recorded during rice growing seasons.

Fertilizer rates were $135 \mathrm{~kg} \mathrm{~N}^{-1} \mathrm{~N}$ as urea, $90 \mathrm{~kg} \mathrm{P}_{2} \mathrm{O}_{5}$ ha $^{-1}$ as calcium phosphate, and $90 \mathrm{~kg} \mathrm{~K}_{2} \mathrm{O} \mathrm{ha}^{-1}$ as potassium chloride. Prior to rice transplanting, fertilizers were broadcasted and incorporated into the top $15 \mathrm{~cm}$ soil by plowing. The rice variety was Liangyoupeijiu for Duntou and Bing 0209 for Dingqiao. The rice seedlings were transplanted at a spacing of $20 \mathrm{~cm} \times 28 \mathrm{~cm}$ with two seedlings per hill. Plastic film, $0.005 \mathrm{~mm}$ thick and $1.7 \mathrm{~m}$ wide, was used to cover the soil in the PM treatment.

\subsection{Soil Sampling and Analyses}

Soil samples were collected from 0 to $15 \mathrm{~cm}$ layer at harvest stage and air-dried and through $0.149 \mathrm{~mm}$ sieve for determining organic matter in every year. Organic matter was tested by Walkley-Black. And fresh soil samples at Duntou were also collected at 5 August, 7 September 2006, which were the tilling and heading stages for the rice. Five random cores were taken from the plow layer $(0-15 \mathrm{~cm})$ of each plot with a $5 \mathrm{~cm}$ diameter tube auger. The samples of PM and UM treatments were mixed thoroughly and sieved (2 $\mathrm{mm}$ mesh) to remove visible plant roots, respectively. For the TF treatment, plant roots were removed by hand. The soil for the molecular analysis was kept immediately at $-20^{\circ} \mathrm{C}$.

\subsection{Molecular Biology Analyses}

The bacterial community structure was also studied by a polymerase chain reaction-denaturing gradient gel electrophoresis (PCR-DGGE) approach [9]. Whole-community total DNA was extracted and PCR were performed according to M. Y. Wu et al. [10].

\subsection{Water Use Efficiency (WUE) Analysis}

WUE was calculated as the amount of grain yield per unit of water used. Water losses due to runoff and leaching were assumed to be negligible [11].

\subsection{Data Analysis}

The difference between different treatments was determined using the least significant difference (LSD) test in the data processing system SAS 8.02 software.

\section{Results and Discussion}

\subsection{Bacterial Community Profile Determined by 16 S rDNA Targeted DGGE}

The DGGE fingerprinting of PCR-amplified 16S rDNA was shown in Figure 1(a) and Figure 1(b), which was extracted from the soils with different treatments at tiller and heading stages. Apparently, the band patterns of three replicate samples from PM, UM, and TF were highly similar (>95\% similarity). The total number of bands in DGGE profiles of different treatments is shown in Table 2. At tiller stage, the total number of bands was 33.3, 23.7, 27.0 for PM, TF, and UM treatment, respectively $\left(\mathrm{p}<0.05^{*}\right)$. At heading stage, the total number of bands was 31.7, 20.0, 28.3 for PM, TF, and UM treatment, respectively $\left(\mathrm{p}<0.05^{*}\right)$. That is, these changes in the number of bands suggest that PM treatment favored the development of a more total bacterial community compared with TF management. One dominant band showed little change among three treatments, suggesting that it may be a predominant bacterial community. It is possible that low $\mathrm{pH}$ in TF management could be responsible for the low numbers of dominant bacterial bands as found on DGGE, because there was an increased pH value in PM management [10] [12].

\subsection{Changes of Organic Matter}

The decreased trend of organic matter content was presented with continuous plastic film mulching under 


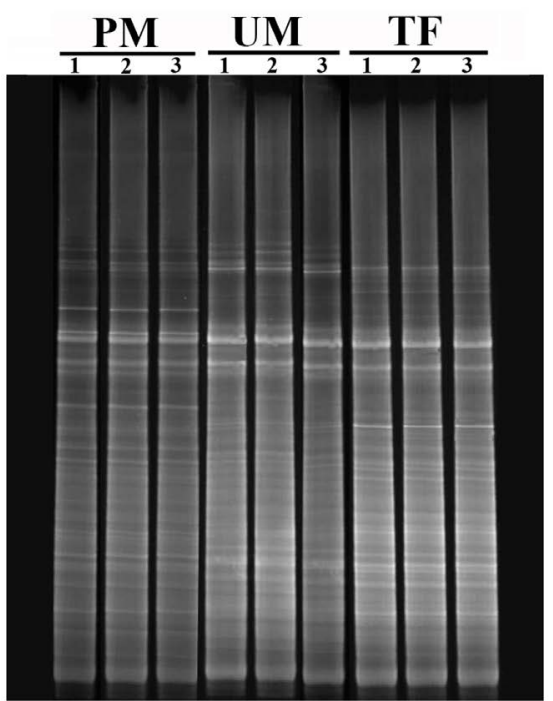

(a)

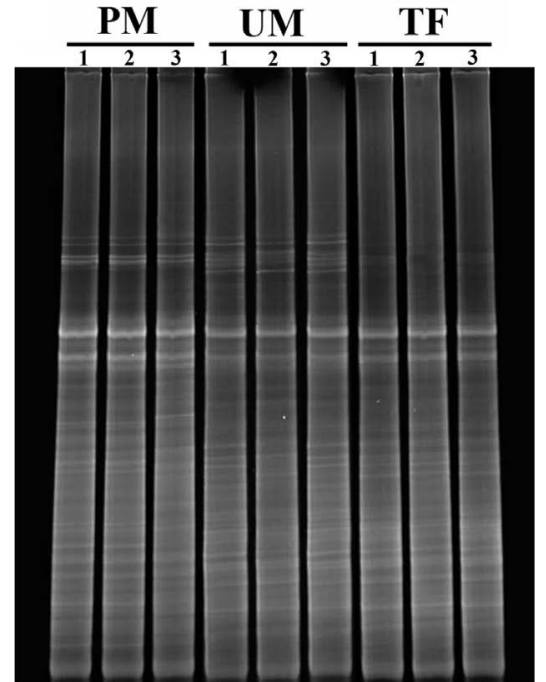

(b)

Figure 1. Denaturing gradient gel electrophoresis gel of bacteria 16S rDNA polymerase chain reaction products amplified from three replicate samples of PM, UM, TF treatment soil-DNA extracts. (a) Tiller stage; (b) Heading stage. PM: nonflooded plastic film mulching cultivation; TF: traditional flooding cultivation; UM: non-flooded cultivation without plastic film mulching; 1, 2, 3: three replicate samples from PM, UM, TF, respectively.

Table 2. Total number of bands in DGGE profiles from PM, TF, UM treatments.

\begin{tabular}{ccc}
\hline Treatment & Tiller stage & Heading stage \\
\hline PM & $33.3( \pm 0.6) \mathrm{a}$ & $31.7( \pm 0.6) \mathrm{a}$ \\
UM & $27.0( \pm 1.0) \mathrm{b}$ & $28.3( \pm 0.6) \mathrm{b}$ \\
TF & $23.7( \pm 0.6) \mathrm{c}$ & $20.0( \pm 1.0) \mathrm{c}$ \\
\hline
\end{tabular}

Standard error is indicated in parentheses $(n=3)$.

non-flooding condition. At Duntou sites, organic matter content were declined by 36.7\%, 28.5\% and 33.9\% under PM, UM and TF, respectively, compared with the initiation (Figure 2). At Dingqiao sites, organic matter content under PM, UM and TF were decreased by 51.4\%, 51.5\% and 40.3\% after 6 years, respectively (Figure 3). The reason for these results is that plastic film mulching increased soil temperature during the entire growing seasons, and resulted of the improving of bacterial community activities and diversities, which promoted the decomposition of organic matter. This was similar to the previous studies [13] [14].

\subsection{Grain Yield and Water Use Efficiency (WUE)}

No significant trend existed in rice yields among the different treatments (Table 3). PM produced similar rice grain yield as TF at Duntou and Dingqiao sites, the average was $7924 \mathrm{~kg} \cdot \mathrm{ha}^{-1}$ and $7015 \mathrm{~kg} \cdot \mathrm{ha}^{-1}$ for PM and 8150 $\mathrm{kg} \cdot \mathrm{ha}^{-1}$ and $6990 \mathrm{~kg} \cdot \mathrm{ha}^{-1}$ for TF. Grain yields in PM had significantly higher than UM plots for two years at two sites, $2.7 \%, 6.1 \%$ at Duntou and $0.8 \%, 8.1 \%$ at Dingqiao, respectively.

Plastic film mulching reduced rice water consumption. During rice growing seasons in different years, the total water consumption in PM plots was 723 - 890 mm, much lower than that in TF plots, which was 1388 - 1591 mm. Irrigation water used in PM was 103 - 253 mm and in UM 196 - 310 mm, which were much lower than those in TF (718 - $947 \mathrm{~mm}$ ). The irrigation water use reduced by 72.8\% - 85.6\% in PM and 66.9 - $72.8 \%$ in UM compared to TF treatment. Water use efficiency (WUE) in terms of grain yield per unit consumed water increased by $70.2 \%-80.4 \%$ for PM and $47.9 \%$ - 63.8\% for UM. Irrigation water use efficiency in terms of grain yield per unit irrigation water improved by $273.7 \%$ - 1300.0\% for PM and $171.8 \%$ - 585.4\% for UM, compared with TF respectively. PM reduced water consumption and increased WUE significantly compared to TF. These results were strongly supported by other studies conducted in the same region or elsewhere [15] [16]. 


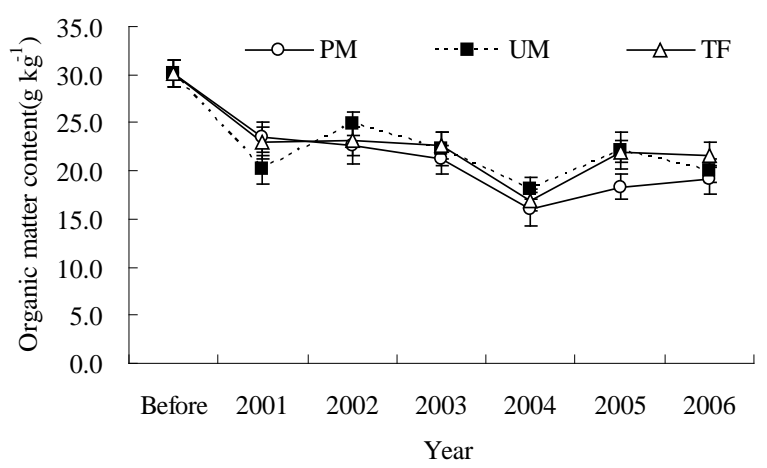

Figure 2. Dynamics of soil organic matter content in different years at Duntou site.

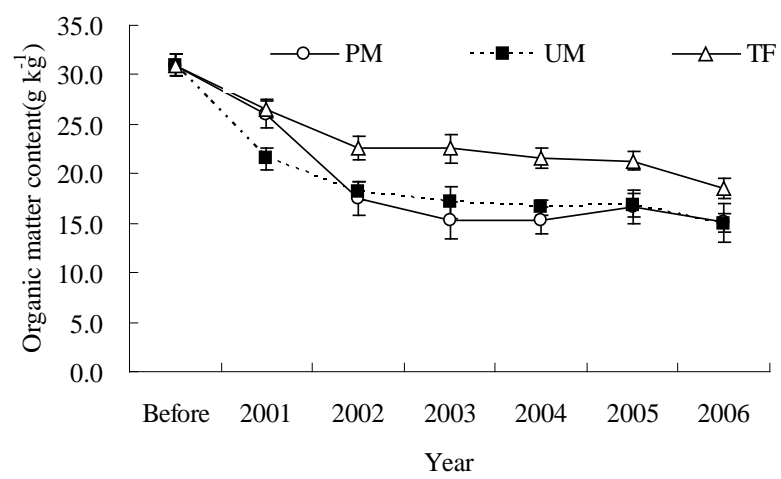

Figure 3. Dynamics of soil organic matter content in different years at Dingqiao site.

Table 3. Effect of plastic film mulching on grain yield and water use efficiency.

\begin{tabular}{|c|c|c|c|c|c|c|c|c|}
\hline Site & Year & Treatment & $\begin{array}{c}\text { Grain } \\
\text { Yield } \\
\left(\mathrm{kg} \cdot \mathrm{ha}^{-1}\right)\end{array}$ & $\begin{array}{l}\text { Irrigation } \\
\text { (mm) }\end{array}$ & $\begin{array}{c}\text { Rainfall } \\
(\mathrm{mm})\end{array}$ & $\begin{array}{c}\text { Water } \\
\text { Consumption } \\
(\mathrm{mm})\end{array}$ & $\begin{array}{c}\text { WUE } \\
\left(\mathrm{kg} \cdot \mathrm{m}^{-3}\right)\end{array}$ & $\begin{array}{c}\text { IWUE } \\
\left(\mathrm{kg} \cdot \mathrm{m}^{-3}\right)\end{array}$ \\
\hline \multirow{6}{*}{ Duntou } & \multirow{3}{*}{2003} & $\mathrm{PM}$ & 8910 a & $251 \mathrm{c}$ & 607 & 858 c & $1.04 \mathrm{a}$ & $3.55 \mathrm{a}$ \\
\hline & & UM & 8670 b & $310 \mathrm{~b}$ & 607 & $917 \mathrm{~b}$ & $0.95 \mathrm{a}$ & $2.80 \mathrm{~b}$ \\
\hline & & $\mathrm{TF}$ & 9000 a & 947 a & 607 & 1554 a & $0.58 \mathrm{~b}$ & $0.95 \mathrm{c}$ \\
\hline & \multirow{3}{*}{2006} & $\mathrm{PM}$ & 6937 a & $253 \mathrm{c}$ & 610 & 873 c & $0.80 \mathrm{a}$ & $2.74 \mathrm{a}$ \\
\hline & & UM & $6540 \mathrm{~b}$ & $308 \mathrm{~b}$ & 610 & $948 \mathrm{~b}$ & $0.71 \mathrm{a}$ & $2.12 \mathrm{a}$ \\
\hline & & $\mathrm{TF}$ & 7300 a & 931 a & 610 & 1590 a & $0.47 \mathrm{~b}$ & $0.78 \mathrm{c}$ \\
\hline \multirow{6}{*}{ Dingqiao } & \multirow{3}{*}{2003} & $\mathrm{PM}$ & 7080 a & $118 \mathrm{c}$ & 655 & $773 \mathrm{c}$ & $0.92 \mathrm{a}$ & $6.01 \mathrm{a}$ \\
\hline & & UM & 7020 a & $201 \mathrm{~b}$ & 655 & $856 \mathrm{~b}$ & 0.82 a & $3.49 \mathrm{~b}$ \\
\hline & & $\mathrm{TF}$ & 7110 a & 733 a & 655 & 1388 a & $0.51 \mathrm{c}$ & $0.97 \mathrm{c}$ \\
\hline & \multirow{3}{*}{2006} & $\mathrm{PM}$ & 6950 a & $103 \mathrm{c}$ & 707 & 890 a & $0.86 \mathrm{a}$ & $6.72 \mathrm{a}$ \\
\hline & & UM & $6430 \mathrm{~b}$ & $195 \mathrm{~b}$ & 707 & $927 \mathrm{~b}$ & $0.71 \mathrm{~b}$ & $3.29 \mathrm{~b}$ \\
\hline & & $\mathrm{TF}$ & $6870 \mathrm{a}$ & 718 a & 707 & $1460 \mathrm{c}$ & $0.48 \mathrm{c}$ & $0.48 \mathrm{c}$ \\
\hline
\end{tabular}

\section{Conclusion}

This study shows that 6-year PM treatment in rice field stimulated the development of total bacterial communities by DGGE, which resulted of the decreased organic matter content in two study areas, and PM also produced similar or higher rice grain yield compared to TF and improved water use efficiency. 


\section{Acknowledgements}

We are grateful to Prof. Yongguan Zhu, Research Center for Eco-Environmental Science, Beijing, China, for providing the testing instrument for the experiment.

\section{References}

[1] Fan, X.L., Zhang, J.P. and Wu, P. (2002) Water and Nitrogen Use Efficiency of Lowland Rice in Ground Covering Rice Production System in South China. Journal of Plant Nutrition, 25, 1855-1862. http://dx.doi.org/10.1081/PLN-120013279

[2] Peng, S., Shen K., Wang, X., Liu, J., Luo, X. and Wu, L.H. (1999) A New Rice Cultivation Technology: Plastic Film Mulching. International Rice Research Notes, 24, 9-10.

[3] Li, Y.S., Wu, L.H., Zhao, L.M., Lu, X.H., Fan ,Q.L. and Zhang, F.S. (2007) Influence of Continuous Plastic Film Mulching on Yield, Water Use Efficiency and Soil Properties of Rice Fields under Non-Flooding Condition. Soil and Tillage Research, 93, 370-378. http://dx.doi.org/10.1016/j.still.2006.05.010

[4] Clasen, A.T., Boyle, S.I., Haskins, K.E., Overby, S.T. and Hart, S.C. (2003) Community-Level Physiological Profiles of Bacteria and Fungi: Plate Type and Incubation Temperature Influences on Contrasting Soils. FEMS Microbiology Ecology, 44, 319-328. http://dx.doi.org/10.1016/S0168-6496(03)00068-0

[5] Bossio, D.A. and Scow, K.M. (1995) Impact of Carbon and Flooding on the Metabolic Diversity of Microbial Communities in Soils. Applied and Environment Microbiology, 61, 4043-4050.

[6] Winding, A., Hund-Rinke, K. and Rutgers, M. (2005) The Use of Microorganisms in Ecological Soil Classification and Assessment Concepts. Ecotoxicology and Environment Safety, 62, 230-248. http://dx.doi.org/10.1016/j.ecoenv.2005.03.026

[7] Liu, M. and Wu, L.H. (2004) Changes of Available Fe, Mn, Zn and Cu Contents among Different Layers of Non-flooded Paddy Soils with Ground Mulching. Journal of Zhejiang University (Agricultural and Life Science), 30, 646-649. (In Chinese)

[8] Liu, X.J., Wang, J.C., Lu, S.H., Zhang, F.S., Zeng, X.Z. and Ai, Y.W. (2003) Effects of Non-flooded Mulching Cultivation on Crop Yield, Nutrient Uptake and Nutrient Balance in Rice-Wheat Cropping Systems. Field Crops Research, 83, 297-311. http://dx.doi.org/10.1016/S0378-4290(03)00079-0

[9] Nakatsu, C.H., Torsvik, V. and Øvreås, L. (2000) Soil Community Analysis Using DGGE of 16S rDNA Polymerase Chain Reaction Products. Soil Science Society America Journal, 64, 1382-1388. http://dx.doi.org/10.2136/sssaj2000.6441382x

[10] Wu, M.Y., Wu, L.H., Zhao, L.M. and Chen, M.M. (2009) Effects of Continuous Plastic Film Mulching on Paddy Soil Bacterial Diversity. Acta Agriculturae Scandinavica Section B-Soil and Plant Science, 59, 286-294. http://dx.doi.org/10.1080/09064710802095024

[11] Cantero, M., Angás, P. and Lampurlanés, J. (2003C) Growth, Yield and Water Productivity of Barley (Hordeum vulgare, L.) Affected by Tillage and N Fertilization in Mediterranean Semiarid, Rained Conditions of Spain. Field Crops Research, 84, 342-357.

[12] Laverman, A.M., Braster, M., Röling ,W.F.M. and Van Verseveld, H.W. (2005) Bacterial Community Structure and Metabolic Profiles in a Forest Soil Exhibiting Spatially Variable Net Nitrate Production. Soil Biology and Biochemistry, 37, 1581-1588. http://dx.doi.org/10.1016/j.soilbio.2005.01.019

[13] Wang, J.K., Zhang, J.H., Xu, X.C., Zhang, X.D. and Zhu, F.C. (1992) Effects of Plastic Film Mulching on Soil Fertility. Journal of Shenyang Agricultural University, 23, 32-37.

[14] Yao, J.G. and Yu, Z.X. (1998) Effects of Plastic Film Mulching on Soil Nutrient. Anhui Agricultural Science Bull, 4, 36-37.

[15] Wu, L.H., Zhu, Z.R., Liang, Y.C., Shi, W.Y. and Zhang, L.M. (1999) A High Yielding, Water-Saving and FertilizerSaving Cultivation Technique for Rice Mulched by Plastic Film under Dry Land Condition. Journal of Zhejiang Agricultural University, 25, 41-42. (In Chinese)

[16] Liu, X.J., Ai, Y.W., Zhang, F.S., Lu, S.H., Zeng, X.Z. and Fan, M.S. (2005) Crop Production, Nitrogen Recovery and Water Use Efficiency in Rice-Wheat Rotation as Affected by Non-Flooded Mulching Cultivation (NFMC). Nutrient Cycling in Agroecosystems, 71, 289-299. http://dx.doi.org/10.1007/s10705-004-6801-4 